\title{
Analysis of Development Trend of Knowledge Economy Management in New Economy Era
}

\author{
Nana Feng ${ }^{1}$, Zhihua Lian², Tangzhan Long ${ }^{3}$ \\ ${ }^{1}$ Macau University of Science and Technology, Macau, China \\ ${ }^{2}$ Tan Kah Kee College, Xiamen University, Fujian Zhangzhou, 363123, China \\ ${ }^{3}$ City University of Macau, Macau, China
}

Keywords: New Economy era, Knowledge economy, Knowledge economy management, Development trend

\begin{abstract}
New economy era mainly refers to knowledge economy era. Under the background of knowledge economy era, the public gradually realize the importance of knowledge economy management and hope to cope with increasingly fierce market competition ands promote better development of economy and society through high-level knowledge economy management. Based on concisely analyzing era features of knowledge economy and knowledge economy management under the background of new economy era, this paper explores development trend of knowledge economy management in detail, in the hope of facilitating sustainable and healthy development of China's knowledge economy management and making corresponding contributions to socialist modernization construction.
\end{abstract}

\section{Introduction}

In the new economy era, China's economic society has preliminarily completed bubblization amendment of new economy and developed to joint construction period of knowledge economy, science and technology civilization. Thus, it exerts very important influence on production and life style of human society. Meanwhile, since most social wealth in the background of knowledge economy era is owned by minority individuals and teams, and the whole distribution is uneven. Hence, the individuals and teams with relatively concentrated wealth play a corresponding role for of knowledge economy management. In the background of knowledge economy era, it is very necessary to analyze development trend of economy management, explore development direction of China's knowledge economy management, correctly guide knowledge economy management and offer corresponding support and reference for socialist modernization construction.

\section{Basic Features of Knowledge Economy Era in New Period}

Just as its name implies, knowledge economy is generated from knowledge development. It is different from economic development mode in Chinese traditional backward places, with distinct era characteristics. Firstly, knowledge itself owns certain particularity. Current theoretical research on world economy cannot accurately position and measure the specific role in the development of knowledge economy. Even relevant information with strong concreteness in knowledge economy system fails to form concrete conclusions. For example, whether innovation belongs to the ability or idea? In other words, in knowledge economy era, knowledge gradually develops to become the source of social service, but it cannot be equal to social service and the two has certain differences ${ }^{[1]}$. Secondly, in current knowledge economy era, the definition of production factors gradually becomes vague. The economic development mode of world economy integration transforms production and life style of the public. All kinds of relent producers gradually tend to assimilation, and the boundary becomes increasingly vague. Thirdly, the development of knowledge economy era is still influenced by traditional economic development environment, and such influence includes positive and negative contents. For instance, certain environmental pollution and economic balance damage are caused while social progress is promoted. Thus, the development of knowledge economy era should adapt to 
traditional economic environment and properly change current economic development environment and create good space for development of knowledge economy management. Finally, under the background of knowledge economy era, enterprises should attach more importance to investment analysis in order to better develop, overall consider factors in various aspects and guarantee comprehensiveness of enterprise development. Asset investment in knowledge economy era should be differentiated with accounting system and actively cope with intangible investment which may be brought for future social public. It is required to measure current economic activity in physical environment and promote better development of China's economy.

\section{Knowledge Economy Management in New Economy Era}

In the background of knowledge economy era in the new period, knowledge economy management is mainly divided into three important stages: knowledge creation, knowledge discovery and knowledge transfer. The three important stages jointly form knowledge economy management system. As the development of technology and reform of knowledge economy management idea, modern society starts to depend on electronic information technology for knowledge economy management, such as transferring information, adjusting working process and changing replica technique by information technology etc. These generate positive influence on development of China's market economy. Meanwhile, under the background of knowledge economy era, enterprises should realize the importance of knowledge economy management during operation and management and clearly know knowledge economy management is a core factor influencing future market competitiveness of enterprises. Therefore, development of knowledge economy management is beneficial to enterprise modernization construction ${ }^{[2]}$.

Knowledge changes destiny. In current society, enterprise destiny change also depends on knowledge to some extent. Correct enhancement of knowledge economy management can boost the level of enterprise human resource management, overall intensify comprehensive quality and work efficiency of enterprise employees and create conditions for enterprises to gain economic benefit and social benefit. In recent years, through joint efforts of relevant government units and large-scale enterprises, China has accumulated certain experience and data for knowledge economy management. The construction of all kinds of rules and regulations also starts. Enterprises occupy certain position in market competition through rational application of knowledge economy management and make corresponding contributions to socialist modernization construction on the basis of driving market economy development.

\section{Development Trend of Knowledge Economy Management in New Economy Era}

\section{Joint Construction of Innovation and Core Ability}

The key content of economy management in new economy era is management of intangible products and especially emphasizes mastery of intellectual products, which to some extent decides development direction of knowledge economy management in new economy era. In current stage, economics and management fields regard knowledge economy management as the key points and deem intangible product - knowledge as the breakthrough of enterprise construction and development in new economy era to promote better development of enterprises ${ }^{[3]}$. However, how to management and innovate for knowledge economy and define development value of knowledge economy cannot be confirmed. Thus, this issue becomes the bottleneck of China's knowledge economy management and imposes adverse effects on modernization construction and development of market economy. Thus, in current background of knowledge economy era, knowledge economy management will certainly place the emphasis in innovation and core ability construction. Next, this paper analyzes the development trend in detail. 


\section{Enterprises carry out innovation management for knowledge economy}

To manage knowledge economy in the background of new economy era, firstly, it is required to define knowledge economy from philosophy level, and specify the differences between knowledge economy management and general information management. In knowledge economy era, knowledge economy mainly includes two types, i.e. knowledge economy which attaches importance to comprehension and knowledge economy with certain development rules. In actual development process, enterprises should enhance attention to the two types of economy, adopt certain measures to facilitate mutual transformation of the two and lay a solid foundation for innovative development of enterprise management work. Meanwhile, the purpose of knowledge economy management is to offer corresponding service and assistance for enterprise innovation. The specific management process can combine with innovation for development. Thus, in knowledge management practice, enterprises should abandon all external influence factors which restrict knowledge economy innovation and create good environment for carrying out knowledge economy management. In addition, for relevant economic entities containing different economy types in different fields, since differences exist in their general economic environment and basic development direction, operation procedure, rules and regulations are also different. Thus, in specific management process, enterprises cannot blindly refer to advanced experience of successful enterprises, but should combine enterprise development to formulate corresponding measures and actively meet era challenges. Therefore, in the background of knowledge economy, enterprises should provide corresponding management level, create favorable management atmosphere, improve managers' basic quality for knowledge economy management and strengthen innovation management trend in order to boost knowledge management level.

\section{Enterprises construct core ability for knowledge innovation management}

In the background of new economy era, enterprises should actively create and present the value in development process and adopt certain measures to construct core working ability of enterprise management team so as to improve market competitiveness and achieve organizational management value. Hence, in the process of core ability construction, enterprise management layer should make every member in the team attach importance to development of their creative ability, improve their comprehensive ability and mastery of relevant knowledge, motivate individual innovation ability to the largest extent and offer corresponding guarantee for knowledge economy management ${ }^{[4]}$. Although for specific management work, various comprehensive qualities and knowledge reserve of employees cannot be objectively measured by the wage, but employees can feel the joy of achieving and creating value in the development process and lay a solid foundation for future development. Hence, enterprises should get rid of the influence of traditional rigid management thought in management process, motivate employees' desire for innovation development, create innovation development opportunity and space for employees' creation and provide human resource guarantee for sustainable and healthy development.

To be more specific, in the background of new economy era, construction of enterprise core ability is still the problem of human resource management pattern. Thus, enterprises should take ability as the orientation in employee management process, attach importance to refined management work of production department and make sure employees' comprehensive abilities are respected on the basis of all-round development so as to offer corresponding support and reference for all-round development of employees.

\section{Re-integration of Talent Structure}

To attach importance to middle managers and promote diversified development of knowledge economy management hierarchy

In current background of new economy era, enterprises should give full play to the function of middle managers in actual management process in order to really facilitate sustainable and healthy development. In other words, top management personnel should enhance attention to middle management personnel, rationally arrange middle management positions and personnel, ensure free control and offer certain structure support for diversified development of economy management in the background of knowledge economy era. 
In Chinese enterprises, the existence and further development of middle management personnel is the inevitable path of further detailing enterprise operation and management department in modern society. Hence, top management personnel should enhance attention to middle management, specify the important significance of enterprise economy development and then give full play to the important function of middle management on knowledge economy management[5]. Influenced by current economic development trend, modern enterprises inevitably operate in multiple fields and own certain operation management risk in new economy era. The existence of middle managers can overall master production and operation risks of enterprises, transfer or evade risks according to actual conditions so as to avoid heavier losses to enterprise operation managers.

Thus, knowledge economy management of middle managers should start from bottom to top and presents sector structure in the background of new economy era. Middle managers exert the role of buttons in the structure. Besides, once enterprises generate corresponding risks in operation development process, middle managers can fast narrow enterprise operation scope through the framework of fan and reduce the unnecessary loss to the large extent. Moreover, the compound of enterprise operation and development also needs middle managers to give play to the important management function. Hence, enhancing attention to middle managers in knowledge economy management is one of inevitable development trends of knowledge economy management in new economy era.

To develop enterprise human resource management in new economy era

In the face of economic development trend of China's new economy era, enterprises should actively explore diversified management mode during human resource management, apply it in management practice and improve management level. At the same time, in actual management process, enterprises should not merely strengthen attention to human resource management, but also should combine dynamic change features of era to coordinate communication and exchange of different cultures and promote sustainable and healthy development of enterprises.

In knowledge economy era, enterprise senior management personnel should realize their important function in human resource management, and boost macro-management ability and micro-operation ability on the basis of giving full play to the role of tutor. Besides, when talent collision happens due to cultural conflict, enterprises should coordinate relevant personnel and offer corresponding guidance for healthy development.

Knowledge economy management in new economy era more needs interdisciplinary talents, so enterprises should attach importance to developing comprehensive ability of employees in human resource management, excavate employees' potential, finally effectively utilize human resource and make corresponding contributions to modernization construction and development. Knowledge economy as an important development feature of new economy era, knowledge economy requires enterprises to strengthen knowledge training and management for employees in current era background and to combine actual development conditions to encourage employees for technical innovation. Furthermore, enterprises are required to offer corresponding economic support and system guarantee for technical support protection, promote employees to feel humanistic care of enterprises and contribute to better facilitating sustainable and healthy development.

\section{Conclusions}

For the study on development trend of knowledge economy management in new economy era, economics and management fields fail to fully cognize it. In the background of new economy era, all kinds of economic forms are in dynamic change and development process, so the development trend cannot be accurately positioned. Thus, enterprises should combine dynamic change features of era and master development trend of knowledge economy management in order to gain better development so that enterprises continuously adjust management mode, train high-quality talents, obtain better development in new economy era and make corresponding contributions to socialist modernization construction. 


\section{References}

[1] Wu Wenqun, Study on Development Trend of Know Economy Management in New Economy Era. Market Modernization, 2013(23):196.

[2] Huang Yi, Exploration of Economy Management Development Trend in New Economy Era. Journal of Changsha University, 2014(3):8-11.

[3] Zeng Zheng, On Development of Knowledge Economy Management in Economy Era. Times Finance (II), 2014(1):72-73.

[4] Wang Kunsheng, On Development of Know Economy Management in Economy Era. Architectural Engineering Technology and Design, 2015(9):3023-3023.

[5] Song Jihua, Li Ya, Development Trend of Management Accounting in New Economy Era. Market Modernization, 2015(7):192-193. 